\title{
MARGINALNE SKUPINE KASNOSTALEŠKOG DRUŠTVA BANSKE HRVATSKE
}

\author{
Petra Kolesarić, Valentina Markasović \\ Filozofski fakultet Osijek \\ Odsjek za povijest \\ pkolesaric97@gmail.com, tina.markasovic@gmail.com \\ Stručni rad \\ Primljeno: 13. 2. 2019. \\ Prihvaćeno 18. 10. 2019.
}

\begin{abstract}
Središnja tema rada jesu marginalne skupine kasnostaleškog društva Banske Hrvatske. U radu se na temelju relevantne literature donosi pregled skupina marginaliziranih ljudi i/ili naroda u prvoj polovici 19. stoljeća na području Banske Hrvatske. Nakon analize strukture društva Banske Hrvatske i objašnjenja pojma marginalnih skupina, rad daje pregled načina života Židova, Roma, skitnica, prosjaka, putujućih zabavljača, zatvorenika, neudanih majki i trudnica, izvanbračne djece, siročadi, bolesnika i invalida. Također je prikazan odnos društva prema navedenim skupinama. Posljednje poglavlje bavi se analizom prikaza marginalnih skupina u odabranim djelima hrvatske književnosti 19. stoljeća.
\end{abstract}

Ključne riječi: marginalne skupine, Banska Hrvatska, Židovi, Romi

\section{Uvod}

Tijekom razdoblja 17. i 18. stoljeća društvene i političke prilike, kao složeni povijesni procesi, na području zemalja Habsburške Monarhije umnogome su utjecale na oblikovanje brojnih sastavnica sociokulturnih identiteta pojedinih skupina u Banskoj Hrvatskoj. Područje koje je obuhvaćala Banska Hrvatska do 1848. godine, posebice se odnosi na Križevačku, Požešku, Srijemsku i Virovitičku županiju čija su područja, u dugom povijesnom trajanju, bila izložena doseljenjima različitih naroda, poput Židova i Roma. U ovom radu se na temelju relevantne literature, s naglaskom na monografiju Iskre Iveljić, Banska Hrvatska i Vojna krajina od prosvijećenog apsolutizma do 1848. godine, nastoji prikazati struktura kasnostaleškog društva Banske Hrvatske, s posebnim osvrtom na marginalne skupine u prvoj polovici 19. stoljeća. Struktura ovog rada podijeljena je u dva dijela kako bi se donio pregled marginaliziranih skupina kasnostaleškog društva Banske Hrvatske. Rad problematizira strukturu kasnostaleškog društva kao i po- 
jam marginalnih skupina, prikazujući posebno Židove, Rome, skitnice, prosjake, zatvorenike, neudane majke, trudnice, siročad, izvanbračnu djecu te bolesnike i invalide. U drugom dijelu rada nalazi se analiza opisa marginalnih skupina u utjecajnijim djelima hrvatske književnosti 19. stoljeća.

\section{Kasnostaleško društvo Banske Hrvatske}

Kasnostaleško ili kasnofeudalno društvo u Banskoj Hrvatskoj bilo je sastavljeno od slojeva plemstva, građanstva i seljaštva. Visoko plemstvo djelovalo je u najvišim državnim službama te su imali mjesto i glas u Zemaljskom saboru. ${ }^{1}$ Srednje plemstvo aktiviralo se kroz županijske skupštine, a pravo na sudjelovanje na istima je 1819. godine dano i seljacima-plemićima. Nositelji političke vlasti bili su i dijecezanski i titularni biskupi, opati i prepošti samostana i kaptola; i oni su imali glas u Hrvatskom saboru. Građanstvo je bilo feudalnog tipa - svatko tko je u gradu posjedovao nekretninu ili se u gradu bavio obrtom, trgovinom ili drugim časnim zanimanjem, mogao je postati građanin. U sloj građanstva su, nakon reformi Marije Terezije i Josipa II., mogli ući i kmetovi koji su napustili podložnički odnos. Građaninom se postajalo polaganjem prisege i plaćanjem pristojbe. Građani su mogli aktivno i pasivno sudjelovati u izboru gradskih čelnika te je porez koji su plaćali bio manji od onog koji su morali plaćati oni koji nisu bili građani. Jezgru građanstva činili su trgovci i obrtnici. Veletrgovci, koji su se obogatili posredničkom trgovinom, povezali su se s novim, intelektualnim slojem, pripadnici kojeg su se bavili slobodnim zanimanjima poput prava i medicine, te su zajedno doprinijeli širenju hrvatske nacionalne ideje, liberalnih ideja i ideja građanskog društva, otvorivši vrata izgradnji modernog građanskog društva Banske Hrvatske. ${ }^{2}$

Do 1848. godine većina seljaka u Banskoj Hrvatskoj bili su kmetovi te su morali davati različite naknade plemiću na čijoj su zemlji živjeli i radili. Odnosi kmetova i plemića bili su regulirani urbarima donesenima u vrijeme Marije Terezije. S pojavom alodijalne ekonomike, u sklopu koje su plemići proizvode sa svojih posjeda počeli plasirati na trži-

1 Arijana Kolak Bošnjak, „Struktura hrvatskog društva u 19. stoljeću i razvoj građanskog društva“, Temelji moderne hrvatske - hrvatske zemlje u „dugom“ 19. stoljeću, ur. Vlasta Švoger, Jasna Turkalj, Zagreb, 2016., 134.: U Hrvatskom saboru su mjestom i glasom sudjelovali i zastupnici slobodnih i kraljevskih gradova. 
šte, dolazi do češćeg kršenja odredbi propisanih urbarima. Zbog toga češće izbijaju i bune kmetova. U pokušaju uklapanja u kapitalističko društvo, seljaci su počeli prodavati proizvode, ali ne viškove, koje nisu ni imali, nego one proizvode koji su im trebali za život. Uključivanje u tržišne procese pridonijelo je raspadu kućnih zadruga i raslojavanju na selu. ${ }^{3}$

U hrvatskim zemljama modernizacija počinje tijekom hrvatskog nacionalnog preporoda, između 1835. i 1875. godine, kada se iz kasnostaleškog društva razvija građansko-kapitalističko društvo. Tradicionalni sustav mogao se promijeniti nakon revolucije 1848./1849. ${ }^{4} \mathrm{Na}$ promjene u društvu utjecale su moderne europske ideje, poput ideja Francuske revolucije, ali glavnu je ulogu imala državna vlast. Vladar, Ugarski sabor te ban i Hrvatski sabor potvrdili su ukidanje kmetstva, čime dolazi do početka novog perioda razvoja društva. ${ }^{5}$

\section{Marginalne skupine}

Kasnostaleško društvo Banske Hrvatske bilo je zahvaćeno horizontalnom i vertikalnom dinamikom i mobilnošću, ali i dalje hijerarhizirano, pa je pripadnost određenom staležu uvelike uvjetovala pravni i materijalni status te svakodnevni život pojedinaca i skupina. Razlike između povlaštenog gornjeg i obespravljenog sloja bile su vrlo izražene. U takvom društvu bilo je lako posrnuti, a potom biti potisnut na rub. Marginalizacija se događala zbog različitih uzroka, moralnih, materijalnih, zdravstvenih i sl. ${ }^{6}$ Pojmom marginalizirani označavaju se oni pripadnici društva koji su udaljeni od tzv. centra društvenog prostora te su sporedni, periferni, i neutjecajni. ${ }^{7}$ Marginaliziranim skupinama mogli su pripadati različiti pojedinci ili cijele zajednice kao Romi, prosjaci, mentalni i teški fizički bolesnici, invalidi, siročad, neudane majke, prostitutke, zatvorenici ili putujući zabavljači od cirkusanata do glumaca. Pripadnost nižim društvenim slojevima nije morala značiti i pripadnost marginalnim skupinama. Primjerice, seljaci koji žive u teškim uvjetima i pripadaju nižim društvenim slojevima i dalje čine dio seljačkog kolektiviteta te imaju svoju ulogu i mjesto. Pojedinac ili sku-

3 Kolak Bošnjak, „Struktura hrvatskog društva“, 135-136.

4 Igor Karaman, Hrvatska na pragu modernizacije (1750.-1918.), Zagreb 2000., 32.

5 Kolak Bošnjak, „Struktura hrvatskog društva“, 133.

6 Iskra Iveljić, Banska Hrvatska i Vojna krajina od prosvijećenog apsolutizma do 1848. godine, Zagreb 2010., 122-123.

7 Zoran Šućur, „Romi kao marginalna skupina“, Društvena istraživanja 9 (2000), br. 2.-3., 212. 
pina postaju marginalnima kada iz određenog razloga budu izbačeni iz svoje zajednice, a ne prihvati ih druga zajednica. Oni su smatrani otpadnicima koji nisu dio društvene zajednice i ne poštuju njezine norme. Često su bili izloženi predrasudama i pogrdama, a organi vlasti su nad njima provodili jaku disciplinarnu kontrolu. Uloga vjerskih zajednica i Katoličke Crkve je dvojbena; s jedne strane ona ima predrasude prema pojedincima i zajednicama koje žive nemoralno, a s druge strane brine se o njima i potiče svoje vjernike na milosrđe. Ovakav odnos ogleda se u postupcima osuđivanja neudanih majki, zatvorenika i sl., ali i u otvaranju sirotišta i bolnica. Uloga crkvenih vlasti u skrbi o ovakvim skupinama, gotovo je posve zamijenila ulogu svjetovnih vlasti. ${ }^{8}$ U daljnjim poglavljima bit će detaljnije opisane marginalne skupine.

\section{Židovi}

Razvijenije zemlje u Habsburškoj Monarhiji su prema Židovima bile tolerantnije, ali oni ipak nisu bili jednakopravni. Banska Hrvatska je prema Židovima imala čvrste zabrane - boravak i naseljavanje nisu im bili dopušteni. Stoga su Židovi bili izloženi čestim porugama te su bili žrtve predrasuda i fizičkih napada. Antisemitizam je bio prisutan u svim slojevima društva i u svim pokrajinama. Josip II. 31. ožujka 1783. godine donosi Patent o toleranciji - točnije, Systematica Gentis Judaicae Regulatio - kojim se Židovima dodjeljuje pravo naseljavanja, ispovijedanja vjere te studiranja. Nakon toga počinje naseljavanje Židova i organiziranje njihovih bogoštovnih općina, koje su morale imati barem deset muškaraca starijih od 13 godina te su se morale prijaviti kod lokalnih vlasti. Općine su bile osnivane u gradovima kao što su Rijeka, Varaždin, Zagreb, ali neki, poput Požege, nisu dopuštali naseljavanje Židova unutar užeg područja grada; zbog toga je 1820. općina osnovana u okolici Požege, ne u samome gradu. Općine su organizirale bogoštovlje, vjerske škole, vjerske pogrebe te dobročiniteljski rad. Osnivane su i dobrotvorne udruge, židovske škole, sinagoge te uređivana groblja. ${ }^{9}$

Patentom iz 1783. godine unesene su i druge promjene u život i prava Židova. Smjeli su iznajmljivati zemlju i baviti se određenim obrtima i trgovinom. Nisu više morali nositi žutu krpu koja je simbolizirala njihov status na margini. Smjeli su brijati brade i nositi sablje,

8 Iveljić, Banska Hrvatska, 122-123.

9 Isto, 89-90. 
rezbariti pečate, proizvoditi barut i trgovati proizvodima od salitre. Međutim, dokumenti pisani na hebrejskom ili jidišu bili su nevažeći - sve je moralo biti pisano latinskim, njemačkim ili mađarskim. Korištenje hebrejskog ili jidiša bilo je zabranjeno, osim prilikom molitve. Godine 1788. uveden je novi antroponimijski sustav prema kojemu su svi Židovi morali uzeti nova prezimena, koja su se često svodila na prijevod hebrejskih riječi na europske jezike, imenovanje po vanjskim tjelesnim karakteristikama ili davanje uvredljivih imena. ${ }^{10}$ Imenovalo se i po zanimanju kojima se osoba bavila (npr. Artz - liječnik, Künstler - umjetnik, Maler-slikar) ili po mjestu ili državi iz koje je dolazila (npr. Stuckert iz Stuttgarta, Prager iz Praga). ${ }^{11}$ Zanimljiv primjer uvredljivog novog prezimena donosi mađarski autor Mór Jókai (1825.-1904). u svome djelu Rab Ráby (1879.); ${ }^{12}$ u romanu Židov moli službenika da se njegovo novo prezime piše Rotheisel, umjesto Rothesel, što znači 'crveni magarac'. ${ }^{3}$

Naseljavanje u svim gradovima osim u rudarskim naseljima, uz stjecanje zemljoposjeda tamo gdje je ta mogućnost i ranije postojala, Židovima je dopustio Ugarski sabor 1840. godine. Zbog te su odredbe Židovi u Hrvatskoj mogli kupovati nekretnine, ali nisu mogli biti upisani kao vlasnici istih. Židovi nisu imali građanska prava niti su mogli biti članovi cehova. Od 1840. dobili su pravo zanata, ali samo ako su im šegrti i kalfe također Židovi. Po zanimanju su bili trgovci, zlatari, prijevoznici, mjenjači, zatim liječnici, pravnici, umjetnici. Bili su aktivni i u dobrotvornom radu te je 1846. godine Jacques Epstein osnovao Zagrebačko društvo čovječnosti. ${ }^{14}$

Dio Židova napustio je ortodoksni tradicionalizam te su se dijelom akulturirali ili prelazili na kršćanstvo. Židovi rođeni u Hrvatskoj, unatoč domoljublju, nisu mogli ostvariti pripadnost socijalnoj i kulturnoj zajednici Hrvatske. Na primjer, brak između pripadnika različitih vjerskih zajednica nije bio moguć. U Austriji su Židovima građanska prava dodijeljena 1848. godine, dok je isto u Banskoj Hrvatskoj učinjeno tek 1873. godine. ${ }^{15}$

10 Ljiljana Dobrovšak, Židovi u Osijeku: od doseljavanja do kraja Prvog svjetskog rata, 2013., 34-35.

11 Julija Koš, Alef bet židovstva: Pogled u krug židovske povijesti, religije i običaja, Zagreb 1999., 108-109.

12 Raphael Patai, The Jews of Hungary: History, Culture, Psychology, Detroit 1996., 216.

13 Mór Jókai, Rab Ráby, Budapest 1994., 39, 45, 47.

14 Iveljić, Banska Hrvatska, 90-91.

15 Isto, 91. 
Neposredno prije revolucije koja im je donijela građanska prava, Židova je u hrvatskim županijama 1847. godine bilo ukupno 1 590: 185 u Virovitičkoj županiji, 310 u Srijemskoj, 740 u Zagrebačkoj te 355 u Varaždinskoj. Međutim, popisi istog autora, mađarskog demografa iz toga vremena, Eleka Fényesa, donose drukčiju demografsku sliku. Popis iz 1840. godine navodi ukupno 2100 Židova u Hrvatskoj, a onaj iz 1851. oko 4000 Židova. ${ }^{16}$

\section{Romi}

Povijesni izvori svjedoče o prisutnosti Roma u hrvatskim zemljama od 14. stoljeća, kada se mogu pronaći u Dubrovačkoj Republici (1362. godine), ali i na području Zagreba (1378. godine). ${ }^{17} \mathrm{U}$ početcima romske prisutnosti na hrvatskom području, stanovništvo je većinom imalo pozitivan ili neutralan odnos prema njima, ponajprije jer su se predstavljali kao kršćani progonjeni od Osmanlija. Međutim, kao posljedica optužbi za vračanje i čarobnjaštvo, otmicu djece, špijuniranje i sl., u 15. stoljeću mijenja se percepcija i odnos prema Romima. ${ }^{18}$ Slijedeći europski model državnog progona Roma, predstavnici hrvatskih vlasti organizirali su institucionalni progon u 16. stoljeću. Vlasti Habsburške Monarhije su u sklopu terezijanskih i jozefinskih reformi pokušale riješiti tzv. „ciganski problem“; bez puno uspjeha. ${ }^{19}$ Romske zajednice su često percipirane kao „oni drugi“, ne samo po razlikama u podrijetlu ili konfesiji, već po načinu života. Međutim, u područjima gdje su bili trajno naseljeni, primjerice u slavonskim županijama, mišljenje i stavovi o Romima nisu bili negativni, štoviše ondašnje stanovništvo je isticalo kako „naši Cigani“ ne kradu. Ipak, Romi koje se naziva Ciganima u najvećem broju slučajeva se ne pokušavaju integrirati u postojeću društvenu strukturu; oni ustraju u nesesilnom načinu života, zaziru od organa vlasti i sl. Ističe se kako oni Romi koji se i odluče naseliti na nekom području često žive u „sklepanim provizornim nastambama od ćerpiča i drva", koje se nalaze na kraju sela ili podalje od njega. Također,

16 Dobrovšak, Židovi u Osijeku, 64.

17 Danijel Vojak, Neven Kovačev, „Theresian and Josephine reform efforts in the regulation of the socioeconomic position of Roma in Croatia and Slavonia", Povijesni prilozi 55 (2019), br. 55., 286.

18 Danijel Vojak, „Iz povijesti Roma u 18. stoljeću: Nikola Škrlec Lomnički o Romima u spisima Status actualis, Projectum i Descriptio“ Zbornik Odsjeka povijesnih znanosti Zavoda povijesnih i društvenih znanosti Hrvatske akademije znanosti i umjetnosti 31 (2013), 198.

Isto, 197. 
mnogi od njih borave u šumama, ispod mostova ili u spiljama, što je razlog negativnih stereotipa o Romima kao o skitnicama, prosjacima, kradljivcima, otimačima djece te bacanju uroka na ljude i pčele. ${ }^{20}$ Prostorna i kulturna marginalizacija Roma te stvaranje etnički izoliranih getova uvjetovalo je i zanimanja kojima su se bavili. ${ }^{21}$ Zanimanja koja se javljaju u Roma jesu prodavači konja, obrađivači drva, svirači te gatanje kao žensko zanimanje. ${ }^{22}$ Uza sve navedeno, nedostatno poznavanje romske kulture, tradicije, jezika i umjetnosti uvjetovalo je njihove progone i stradanja, a često nisu mogli izbjeći niti opravdane optužbe za zanimanja kojima su se bavili, ponajprije gatanje i prijevare. ${ }^{23}$

Najveći dio romske populacije u Habsburškoj Monarhiji je bio naseljen u sjevernim i zapadnim ugarskim županijama. Njihova socijalna i ekonomska struktura je počivala na obiteljskom, ali i plemenskom zajedništvu, koje se ogledalo u običajima, jeziku te zanimanjima kojima su se bavili. Prema tome, plemenska skupina koja se bavila obradom metala se nazivala Kalderašima ${ }^{24}$, a oni koji su se bavili obradom drva Koritarima. Održavanje strukture plemenske zajednice se temeljilo na endogamnim vezama, a utemeljenje obitelji je započinjalo običajem tzv. kupnje ili dogovorene otmice djevojke. ${ }^{25}$

Terezijanskim i jozefinskim reformama prosvijećenog apsolutizma, nastojalo se odviknuti Rome od nesesilnog načina života i njihovih običaja. To je podrazumijevalo zabranu: ženidbe unutar obitelji, uporabe jezika, bavljenja nedostojnim zanimanjima te čergarenja. Romska djeca su često davana na preodgoj kršćanskim obiteljima. Uvođenjem služenja vojne obaveze, Romima se nametnulo novo ime Neubauer, odnosno novi seljaci ${ }^{26}$, pojam koji je trebao označiti prijelaz Roma na sjedilački način života. ${ }^{27}$

20 Iveljić, Banska Hrvatska, 123.

21 Šućur, „Romi kao marginalna“, 219-221.

22 Iveljić, Banska Hrvatska, 123.

23 Hrvatić, „Romi u Hrvatskoj“, 369.

24 Goran Đurđević, Povijest i običaji autohtonih hrvatskih Roma - Lovara, Bjelovar, 2009., 30.: Od rumunjske riječi za kotao - kotlokrpe. Iveljić, Banska Hrvatska, 124.; Prisutnost Roma Kalderaša vidljiva je u kotaru Koprivnica i kotaru Đurđevac, a zapisana u matičnim knjigama župe Pitomača u razdoblju od 1768. do 1857. godine.

25 Iveljić, Banska Hrvatska, 124.

26 Vojak, „Iz povijesti Roma“, 201-202.: Marija Terezija je, nastojeći riješiti „Ciganski problem“, 1761. godine donijela odredbu, prema kojoj je ime „Cigani“, odnosno „Zigani“ zamijenjeno „Novim građaninom“ (mađ. „Ujpolgár") ili „Novo seljakom“ („Ujparasztok“, njem. „Neubauern“) ili „Novo Mađarom“ (mađ. „Ujmagyar") ili „Novo naseljenikom“ (mađ. “Ujlakosak“, lat. „Novocolonus“). Istom je odredbom uvedena i vojna obuka za Rome starije od šesnaest godina, a za one između 12 i 16 godina je bila propisana cehovska odluka.

Iveljić, Banska Hrvatska, 124. 
Izravna mjera u terezijanskoj, odnosno jozefinskoj regulaciji romskog položaja bila je provedba prvog popisa stanovništva koje obuhvaća i romsko stanovništvo te je prostorno proveden na području Križevačke, Požeške, Srijemske i Virovitičke županije. ${ }^{28}$ Zaziranje od svakog oblika organizirane vlasti, pa tako i popisa stanovništva od strane Roma dovelo je do činjenice da je broj Roma zahtjevno ustvrditi. Iako su popisivani kao zasebna narodna skupina, u mnogim slučajevima su zbog rumunjskog jezika kojim su govorili smatrani Rumunjima ili pak svrstavani u rubriku ostali. Prvi su puta popisani u posebnim popisima od 1780. do 1783. godine. U ovom razdoblju bilježi se primjetan pad broja Roma, kako na području Habsburške Monarhije, tako i u Banskoj Hrvatskoj. Međutim, ove brojke treba uzeti sa zadrškom. Naime, 1781. godine u Habsburškoj Monarhiji je bilo 38 312, a u Hrvatskoj 1323 Roma, dok je 1783. godine u Monarhiji bilo 30 241, a u Hrvatskoj 567 Roma. U prvom popisu stanovništva (1781. godine), najviše je Roma bilo u Virovitičkoj županiji ${ }^{29}$, njih 648, i u Srijemskoj 407, a dvije godine kasnije u Virovitičkoj županiji se, prema popisu, ne nalazi niti jedan Rom. Budući da Romi nisu obuhvaćani popisima do 1851. godine, kada ih je u Habsburškoj Monarhiji bilo 83 769, a u Hrvatskoj 1456 (najviše u Osječkoj županiji - 1 214), nemamo podataka o točnom broju Roma u Banskoj Hrvatskoj. Međutim, važno je istaknuti da je polovica 19. stoljeća vrijeme doseljavanja Roma u Hrvatsku, pa tako oni u popisu iz 1857. godine čine $0,20 \%$ stanovništva Banske Hrvatske. ${ }^{30}$

\section{Skitnice i prosjaci}

Skitnice i prosjaci bili su svakodnevna pojava, kako unutar Habsburške Monarhije, tako i u Banskoj Hrvatskoj. ${ }^{31}$ Habsburška Monarhija nastojala je i prije 1848. donijeti određene zakone o ljudima koji su socijalno ugroženi, no tek nakon 1848., a posebice 1860 . godine, briga o socijalno ugroženima dobiva zamah. ${ }^{32}$ Skitnice i prosjaci su, kao

28 Vojak, „Iz povijesti Roma“, 205.

29 Isto, 205.: Udio Roma je u Banskoj Hrvatskoj bio najveći na području Virovitičke županije, što se može objasniti blizinom Ugarske u kojoj je živio veći broj romskog stanovništva koji je najvjerojatnije migrirao u pogranični prostor.

30 Iveljić, Banska Hrvatska, 124.

31 Isto, 125.

32 Susan Zimmermann, Divide, Provide, and Rule: An Integrative History of Poverty Policy, Social Politcy, and Social Reformi n Hungary under the Habsburg Monarcyh, Budapest, 2011., 7. 
i romsko stanovništvo, često bili nesesilni. Među njima bilo je i onih kojima je to bio način života, ali i onih koji su to postali zbog nepovoljnih životnih prilika koje su ih snašle. Neki od njih su se prosjačenjem bavili samo periodično, ovisno o vlastitim potrebama. Budući da su se uvijek kretali, njihov broj, kao niti svakodnevicu, nije bilo moguće dokumentirati. Može se pretpostaviti da su se kretali u manjim skupinama, znajući gdje bi mogli prenoćiti, pronaći hranu ili dobiti milodar. Uvijek su prosjačili izvan svojega kraja jer se prosjačenje smatralo sramotom. Vjerske zajednice su nerijetko organizirale veća okupljanja nego svjetovne vlasti kako bi se prosjacima osigurala hrana ili smještaj te udijelio milodar. Najčešće su prosjačili bogalji ili slijepi ljudi, djeca i starci, odnosno svi oni koji su svojim nedužnim dječjim ili staračkim izgledom privlačili pozornost i izazivali sućut. ${ }^{33}$

\section{Putujući zabavljači}

U Habsburškoj Monarhiji putujući zabavljači spominju se već u 18. stoljeću. ${ }^{34}$ Kao što je slučaj i s Romima i skitnicama, putujući zabavljači vodili su nesjedilački život koji ih je smjestio na margine društva. Ti su zabavljači djelovali u cirkusima, menažerijama i glumačkim družinama. Pučko kazalište je kod režimskih predstavnika izazivalo strah - ono je bila pozornica na kojoj se mogla izraziti kritika i oporba vlasti - te su i sudionici tih kazališta bili pod prismotrom. Zabavljači su, ipak, mogli društveno napredovati te postati glumci u kazalištima većih gradova. Primjer društvenog preokreta može se pronaći u životu Josipa Freudenreicha, koji je napustio trgovački zanat kako bi se posvetio glumi te je postao putujući glumac, oženio se suradnicom te glumio diljem Monarhije, a kasnije je postao autor kazališnih komada Graničar i Crna kraljica, a upravljao je i zagrebačkim kazalištem. ${ }^{35}$

Osim glumaca, čiji je repertoar uključivao vesele doskočice, operete, opere i druge komade, zabavljači su bili i čarobnjaci, gutači vatre, atlete, gatare i romske družine s medvjedima. Oni su bili neizostavni dijelovi sajmova, najvećih društvenih događaja. ${ }^{36}$

33 Iveljić, Banska Hrvatska, 125.

34 Više o tome u: Charles W. Ingrao, The Habsburg Monarchy, 1618-1815, Cambridge 2019.

35 Iveljić, Banska Hrvatska, 124-125.

36 Dobrovšak, „Kvaliteta življenja“, 229. 


\section{Zatvorenici}

Krajem 18. i početkom 19. stoljeća europski zatvorski sustav se u znatnoj mjeri reformira. Iako se na području Banske Hrvatske značajne promjene događaju tek nakon ukinuća feudalnog sustava 1848. godine, što izlazi iz vremenskih okvira ovoga rada, početne težnje prema reformama javljaju se upravo u razdoblju kasnostaleškog društva. ${ }^{37} \mathrm{Za}$ dokazivanje osuđenikove krivnje se do neoapsolutizma koristilo inkvizicijskim postupcima. Za vrijeme prosvijećenog apsolutizma se ukida tortura tijekom istrage. Ako je bio nepismen, optuženik nije mogao niti sastaviti obranu, a sudski postupak nije bio niti javan niti usmen. To je dovodilo do osuđivanja nevinih ili do izricanja strože kazne nego što je to prijestup ili zločin zahtijevao. Osobe se moglo teretiti i optužbom za verbalni delikt i usmenu uvredu vladara i članova dinastije, što je bio težak prijestup. Politički prijestupi zahtijevali su nošenje okova. Životni uvjeti su u zatvorima bili iznimno loši - zatvorenici su život provodili u tijesnim i mračnim tamnicama nehigijenskih uvjeta, uz oskudnu i lošu prehranu. Nije im bilo omogućeno kretanje. Posjete su mogli primati u ograničenoj mjeri, a pravo na uvjetni dopust nije postojalo. Tek se reformama bana Ivana Mažuranića uvodi ukidanje okivanja i uvjetni dopust. Po isteku kazne, sada bivši zatvorenici nastavljali su živjeti na margini društva jer su bili obilježeni svojim prijašnjim prijestupima i provođenjem vremena u zatvoru. ${ }^{38}$

\section{Neudane majke i trudnice, izvanbračna djeca i siročad}

Trudnice i majke koje nisu imale muža bile su izložene moralnoj osudi. ${ }^{39}$ Njihov je položaj mogao biti poboljšan ako im je socijalni i materijalni status bio dobrostojeći ili su im obitelji i partner bili spremni pomoći. Žene iz viših slojeva su se poslije moralne osude često udavale; izvanbračno dijete bilo bi predano časnim sestrama ili dano na selo. U urbanim je sredinama izvanbračne djece bilo više nego na selu, gdje je postojala manja mogućnost zbrinjavanja djece. U ruralnim je sredinama čest slučaj bilo i kršenje svećeničkog celibata, pri čemu je svećenik ponekad živio u zajednici s nevjenčanom ženom i njihovom zajednič-

37 Igor Josipović, Funkcioniranje zatvorskog sustava u drugoj polovici 19. stoljeća, Zagreb 2018., 1.

38 Iveljić, Banska Hrvatska, 125.

39 Isto, 126.: Treba istaknuti da očevi nezakonite djece nisu bili izloženi moralnoj osudi jednako kao majke, a često su potpuno izbjegli stigmatizaciju. 
kom djecom. Broj izvanbračne djece raste s procesom modernizacije. Po knjizi Petra Matkovića iz 1860-ih, u Banskoj Hrvatskoj bilo je 4.6\% takve djece, dok je u Krajini bilo $1.8 \%{ }^{40}$ Izvanbračna djeca su od rođenja bila stigmatizirana, no to nije nužno značilo da nisu mogla izgraditi društveno prihvatljivu egzistenciju. ${ }^{41}$ Djeca koja izgube roditelje mogla su biti marginalizirana ako nisu potjecala iz dobrostojeće obitelji koja se mogla pobrinuti za njih nakon smrti njihovih roditelja. U ruralnim krajevima te u obiteljima niskog građanstva, skrbnicima je postajala rodbina ili krsni kumovi. Ako nije bilo moguće pronaći skrbnika koji je bio voljan odgajati dijete, djecu bi se ostavljalo u sirotištima, većinom crkvenim. Tamo bi imala osiguranu hranu i smještaj, odjeću te školovanje, ali bi bila izložena strogom disciplinarnom odgoju. ${ }^{42}$

\section{Bolesnici i invalidi}

Tijekom 18. i dijelom 19. stoljeća loši životni uvjeti, jednolična prehrana i slaba zdravstvena zaštita utjecali su na razvoj različitih bolesti poput tifusa, dizenterije, groznice, malarije, tuberkuloze i spolnih bolesti. ${ }^{43} \mathrm{Na}$ rubu društva mogli su se nalaziti i mentalni i fizički bolesnici, kao i invalidi. O njihovoj obiteljskoj i materijalnoj situaciji ovisilo je hoće li biti gurnuti na rub društva, no uglavnom nisu uspjeli izbjeći predrasude. Praznovjerje o bolesnima bilo je prisutno i u selima i u gradovima; naime, nedostatci i poremećaji - i tjelesni i mentalni - mogli su se objasniti kao Božja kazna ili urok. Na selu je pogotovo važno biti zdrav, jer je jedino fizički sposobna osoba mogla doprinijeti u obavljanju poslova neophodnih za opstanak obitelji i zajednice. Bolesnici su u slučajevima nekih bolesti, poput gube, bili potpuno izolirani zbog nepoznavanja pravilne procedure liječenja. ${ }^{44}$

Pod utjecajem ideja Francuske revolucije građansko društvo angažira se u pomaganju slojevima društva koji sami sebi teško osiguravaju preživljavanje, uključujući invalide, starce i siročad. U Zagrebu je 1846. godine osnovana humanitarna udruga „Društvo čovječnosti“. Jedna od komponenti humanitarnosti su i pučke kuhinje, koje financiraju bogatiji građani, a u kojima njihove supruge ponekad volontiraju. U Francuskoj

40 Iveljić, Banska Hrvatska, 126.: Može se pretpostaviti da su ovi postotci nerealni, jer podatci iz 1876. godine ukazuju na to da udio u županijama u Banskoj Hrvatskoj iznosi 5\%, u gradovima 25\%; u Bjelovaru, npr. postotak između 1830. i 1847. iznosi 22.64\%. Isto.

42 Isto.

43 Dobrovšak, „Kvaliteta življenja“, 221-222.

44 Iveljić, Banska Hrvatska, 126. 
se takve ustanove pojavljuju već od 1812.; u Beču se pučka kuhinja otvara tek 1873., a u Zagrebu 1875. Zagrebačku pučku kuhinju osnovala je upravo udruga „Društvo čovječnosti“. ${ }^{5}$ Početkom 19. stoljeća su u Varaždinu postojali hospitali koji su primali siromašne luetične ili psihički bolesne osobe. S vremenom je briga za nemoćne i oboljele postala organizirana skrb. Tako je u Varaždinu humanitarno društvo „Varaždinskih dobročinstava složnost“, osnovalo prvu bolnicu 1859. godine. ${ }^{46}$

\section{Marginalne skupine u hrvatskoj književnosti 19. stoljeća}

Radnja pripovijetke „Tena“ (1894.) Josipa Kozarca (1858.-1906.) odvija se u drugoj polovici 19. stoljeća, nakon raspada kućnih zadruga, što je vidljivo iz situacije Teninog oca, Jerka Pavletića: „Kada se je zadruga raspala, bilo je njemu trideset godina, i sada preko noći morade

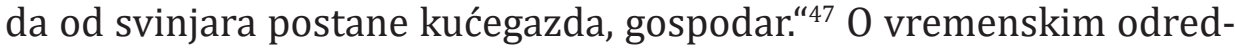
nicama saznajemo i iz toga što se Tenina prva i prava ljubav, pripadnik austrougarskih četa Jaroslav Beranek, na kraju pripovijetke vraća iz Bosne, u čijoj je okupaciji sudjelovao. Unatoč tome što je radnja smještena u vrijeme koje prelazi vremenski okvir ovoga rada, odnos prema marginalnim skupinama se nije značajnije promijenio te nam i ovo djelo može pružiti uvid u sliku kasnostaleških društvenih odnosa. Od marginalnih skupina Kozarac najviše progovara o Romima. Navodi:

„U bogata posavska sela nastanili se Cigani već odavna: jedni su kovači, drugi koritari, a rijetko se koji i pluga latio. Taj svoj zanat tjeraju oni samo naoko, uistinu su pak pravi nesretnici. Da je tomu tako, slijedi već iz toga da se naseljuju samo u najbogatije predjele, a gdje je sirotinja, tu ih nema. (...) U neku ruku slični su oni ljudima à la Leon Jungman: i jedne i druge uzdržava tuđa zemlja za koju oni ne mare, za koju oni ne rade, već su samo dotle u njoj dok im račun podnaša." 48

Citat donosi spisak pojedinih zanimanja kojima su se Romi bavili, a vidljivo je i da im se zamjera nesjedilački način života, koji autor tumači kao iskorištavanje zemlje i ljudi koji tu zemlju naseljavaju. ${ }^{49}$

45 Aleksandra Muraj, „Svakodnevni život u 19. stoljeću“, Temelji moderne Hrvatske - hrvatske zemlje u „dugom“ 19. stoljeću, ur. Vlasta Švoger, Jasna Turkalj, Zagreb 2016., 330.

46 Dobrovšak, „Kvaliteta življenja“, 232.

47 Josip Kozarac, „Tena“, Pripovijetke, ur. Oto Šolc, Marija Peakić-Žaja, Zagreb 1973., 66.

48 Isto, 91.

49 U većoj mjeri autor ipak zamjera hrvatskom stanovništvu što zanemaruje svoje posjede, a što u djelu i u povijesnoj zbilji iskorištavaju strani akteri - Nijemci koji sijeku slavonske šume i Česi koji se naseljavaju u propalim slavonskim selima. 
U djelu se tematizira i položaj bolesnika u društvu. U trećem dijelu pripovijetke Tena razmišlja: „sjetila se i Ruže Ljubićeve kojoj su po čelu i nosu kraste kao dlan velike izrasle te joj koža ostala kao da je na ognju opaljena - a negdje je bila ljubovca velikoga gospodina - pa onda ona Kaja Apićeva... Protrnula je na pomisao kako se sada svatko od njih odvraća, kako se svakome gade, a negda se za njima čitavo selo otimalo!" ${ }^{40}$ Citat, osim što je naznaka preokreta koji očekuje i Tenu koja pred kraj djela oboli od kozica, ukazuje na to da su bolesnici, pogotovo oni čija je bolest imala fizičku manifestaciju, bili društveno stigmatizirani. I Jaroslav Beranek, koji je u Bosni izgubio desnu ruku, boji se društvene osude i da ga Tena neće prihvatiti zbog njegovog invaliditeta. $^{51}$

Roman Augusta Šenoe (1838.-1881.) Prosjak Luka prvi put je objavljen 1879. godine. U njemu autor donosi pogled na loš socijalni položaj siročadi. Naslovni junak, nakon što ga je gradski stražar pronašao na ulici kao novorođenče, otpremljen je u „varošku kuću“, nakon čega su ga dali na skrb starici od koje je, zbog lošeg tretmana kojemu je bio izložen, uskoro pobjegao. Potom su ga smjestili u „gradsku kuću“, „neka pere i mete za onaj kukavni zalogaj što ga ostaviše zatvoreni lopovi.“52 Varoška, odnosno gradska kuća je ovdje pritvor. Zbog toga je Luka kao dijete „[č]uo kletve propalica, čuo hripavi smijeh razbojnika, vidio iskipjelo lice varalice i ono bezočno čelo razuzdane žene koja ti dokazuje da u zvijeri ima više stida nego u čovjeka, a sav taj gad gledao je odrpanog dječaka oholo preko ramena, sav taj smet gurnuo bi šakom, doviknuo mu kroz paklen smijeh: Kopile!"53 Iz citata se iščitava kako autor opisuje da su se čak i zatvorenici, i sami marginalizirani, prema siročadi odnosili s podsmjehom i porugom, što može ukazivati na vrlo nizak položaj siročadi u društvu. Po pročitanom, djeca koja nisu imala roditelje te su se o njima skrbili u javnim ustanovama, bila su izložena ne samo uvredama, već i teškim životnim uvjetima zbog nedostatka hrane te prljavog, hladnog prostora u kojem su obitavali. Opis zatvora govori i o uvjetima u kojima su se nalazili oni utamničeni: „mračni, zadušljivi zrak“ te prenapučeni, skučeni prostor. ${ }^{54}$

50 Kozarac, „Tena“, 87.

51 Isto, 100.

52 August Šenoa, Prosjak Luka, U: Prosjak Luka, Prijan Lovro. Ur. Zvonimir Majdak, Zagreb 1985., 22-23.

53 Isto, 23.

54 Isto, 23-24. 
Nakon što su ga izbacili i iz gradske kuće, Luka se sprijateljio s Matom, koji ga je naučio prosjačkome zanatu: „E, slijepcima je bolje, njima ne treba toliko komedije. (...) No vidite, mi šepavci već smo komedijaši. Sjedni, stisni glavu među ramena, nakrivi lice ko ranjeni svetac, drži svoju nogu rukama uvis, vrgni preda se šešir pak mucaj, brate, i previjaj se, kao da si octa popio.“55 Takve i slične predstave izvodili su dok su obilazili kuće, proštenja i sajmove. Prebivali su u Matinom stanu, koji se sastojao od krova od kukuruzinja, podstave od šušnja, a bio je izrovan u zemlji. ${ }^{56}$ Sve to govori o teškom položaju prosjaka koji su morali izmišljati načine vlastitog preživljavanja.

U putopisnome djelu Putositnice (1845.) autora Antuna Nemčića (1817.-1849.), koji je bio suvremen kasnostaleškome društvu o kojemu govori ovaj rad, može se pronaći nekoliko opaski o Židovima. Iz citata „Židovi nemaju sasvim krivo, kada novac tako definiraju: rif, polag kojega se mjeri roba i čovjek ${ }^{\text {“57 }}$ vidi se da je bila prisutna predrasuda o Židovima kao iznimno povezanima s novcem, kao lihvarima. Dok opisuje Trg sv. Marka u Veneciji, autor ubacuje: „Židova - a gdje ovih nema? - nije također manjkalo,"58 iz čega se može zaključiti da su, nakon ukidanja zabrane o naseljavanju 1840., u Banskoj Hrvatskoj i na obližnjim prostorima Židovi bili brojni.

\section{Zaključak}

Unatoč društvenoj marginalizaciji određenih pojedinaca i skupina u Banskoj Hrvatskoj, poput Židova, Roma, skitnica, prosjaka, putujućih zabavljača, zatvorenika, bolesnika i invalida, neudanih majki i trudnica, siročadi i izvanbračne djece i dr., historiografski izvori ih nisu u potpunosti marginalizirali. Njihova prisutnost bilježi se i od prvih popisa stanovništva, što je vidljivo u popisima s romskom i židovskom populacijom. Ipak, ti popisi se ne mogu proučavati kao potpuno točni, zbog velikih amplituda u rezultatima popisa koji su provedeni na istim područjima s kratkim vremenskim razmakom. Do tih razlika dolazi zbog neusavršenog provođenja popisa - neki su stanovnici upisivani u kategoriju „ostali“, a ponekad su se popisivale samo glave obitelji, kao što je slučaj sa židovskim zajednicama, te su dobiveni podatci samo o broju obitelji, a ne o broju pripadnika. Dru-

55 August Šenoa, Prosjak Luka, 26.

56 Isto, 28-30.

57 Antun Nemčić, Putositnice, Vinkovci 1998., 22-23.

58 Isto, 101. 
ge grupe bilo je još teže popisati te, zbog samog načina njihovog života, ne postoje točni podatci o broju skitnica i prosjaka, kao niti za putujuće zabavljače. Međutim, reformama zatvorskog sustava uvode se i sve učestaliji popisi zatvorenika, koji svjedoče o osobnim podacima zatvorenika, ali i o vrstama kaznenih djela. O neudanim majkama i trudnicama, koje su nosile stigmu nemoralnog ponašanja, ali i o siročadi te izvanbračnoj djeci izvori sporadično spominju životne uvjete, no oni su zasigurno bili nezavidni. Primjeri degradacije iz plemićkog, građanskog društva ili seljaštva vidljivi su u osobama bolesnika i invalida.

Književna djela koja potječu iz razdoblja kasnostaleškog društvenog uređenja Banske Hrvatske ili iz razdoblja koje je netom slijedilo pružaju uvid u društveni položaj određenih marginalnih skupina. Iz djela Josipa Kozarca, Augusta Šenoe i Antuna Nemčića saznajemo o predrasudama koje su zahvatile pripadnike marginalnih skupina te o njihovim zanimanjima i svakodnevici.

Zbog njegovog opsega rad je ograničen na sedam društvenih skupina koje su bile marginalizirane u kasnostaleškoj Banskoj Hrvatskoj te su u radu one prikazane kroz monografije i članke, povijesne izvore te književna djela; međutim, ima prostora za daljnja istraživanja koja će pobliže objasniti položaj ovih skupina ili obuhvatiti i druge skupine koje su se nalazile na rubu društva.

\section{Bibliografija}

\section{Knjige i članci}

Dobrovšak, Ljiljana. „Kvaliteta življenja u sjeverozapadnoj hrvatskoj kroz povijest s naglaskom na grad Varaždin." Radovi Zavoda za znanstveni rad Varaždin 28 (2017), br.1: 213-245.

Dobrovšak, Ljiljana. Židovi u Osijeku: od doseljavanja do kraja Prvog svjetskog rata. Osijek: Židovska općina Osijek, 2013.

Đurđević, Goran. Povijest i običaji autohtonih hrvatskih Roma - Lovara. Bjelovar: Centar savjetovanja, edukacije i kulture Roma, 2009.

Hrvatić, Neven. „Romi u Hrvatskoj: od migracija do interkulturalnih odnosa“, Migracijske i etničke teme 20 (2004), br.4: 367-385.

Ingrao, Charles W. The Habsburg Monarchy, 1618-1815. Cambridge: Cambridge University Press, 2019.

Iveljić, Iskra. Banska Hrvatska i Vojna krajina od prosvijećenog apsolutizma do 1848. godine. Zagreb: Leykam International, 2010.

Jókai, Mór. Rab Ráby. Budapest: Editorg Kiadó, 1994. 
Karaman, Igor. Hrvatska na pragu modernizacije (1750.-1918.). Zagreb: Naklada Ljevak, 2000.

Kolak Bošnjak, Arijana. „Struktura hrvatskog društva u 19. stoljeću i razvoj građanskog društva“. U: Temelji moderne Hrvatske - hrvatske zemlje u „dugom“ 19. stoljeću, ur. Vlasta Švoger, Jasna Turkalj, 133-150. Zagreb: Matica hrvatska, 2016.

Koš, Julija. Alef bet židovstva: Pogled u krug židovske povijesti, religije i običaja. Zagreb: vlast. nakl., 1999.

Kozarac, Josip. „Tena.“ U: Pripovijetke, ur. Oto Šolc, Marija Peakić-Žaja. Zagreb: Mladost, 1973.

Muraj, Aleksandra. „Svakodnevni život u 19. stoljeću“. U: Temelji moderne Hrvatske hrvatske zemlje u „dugom“ 19. stoljeću, ur. Vlasta Švoger, Jasna Turkalj, 309-346. Zagreb: Matica hrvatska, 2016.

Nemčić, Antun. Putositnice. Vinkovci: Riječ, 1998.

Patai, Raphael. The Jews of Hungary: History, Culture, Psychology. Detroit: Wayne State University Press, 1996.

Šenoa, August. Prosjak Luka. U: Prosjak Luka. Prijan Lovro, ur. Zvonimir Majdak. Zagreb: Mladost 1985.

Šućur, Zoran. „Romi kao marginalna skupina.“ Društvena istraživanja 9 (2000), br. 2-3: 211-227.

Vojak, Danijel, Kovačev, Neven. „Theresian and Josephine reform efforts in the regulation of the socioeconomic position of Roma in Croatia and Slavonia", Povijesni prilozi 55 (2018), br.55: 285-303.

Vojak, Danijel. „Iz povijesti Roma u 18. stoljeću: Nikola Škrlec Lomnički o Romima u spisima Status actualis, Projectum i Descriptio". Zbornik Odsjeka povijesnih znanosti Zavoda povijesnih i društvenih znanosti Hrvatske akademije znanosti i umjetnosti 31 (2013): 197-215.

Zimmermann, Susan. Divide, Provide, and Rule: An Integrative History of Poverty Policy, Social Policy, and Social Reform in Hungary under the Habsburg Monarchy. Budapest: CEU Press, 2011.

\section{SUMMARY}

The central topic of the paper is marginalized groups in the late feudal society that is the Kingdom of Croatia. The paper is based on relevant bibliography and gives an overview of the groups of marginalized people and/or nationalities in the Kingdom of Croatia in the first half of the 19th century. After the analysis of the social structures of the Kingdom, the paper gives an overview of the ways of life of Jews, Roma people, vagabonds, beggars, travelling showmen, prisoners, single mothers, pregnant women, illegitimate children, orphans, sick people, and disabled people. The paper also shows how the aforementioned groups were treated by the society. The last chapter deals with the analysis of the representation of marginalized groups in several works of Croatian 19th century literature.

Keywords: marginalised groups, Kingdom of Croatia, Jews, Roma 